\title{
Problematyka budżetowa w ustawie o związkach metropolitalnych
}

\section{Budgeting Issues in the Act on Metropolitan Unions}

Streszczenie. Uchwalona w 2015 r. ustawa o związkach metropolitalnych z założenia ma charakter aktu prawnego o charakterze kompleksowym. Zawiera ona unormowania dotyczące ustroju i zadań związków oraz podstaw gospodarki budżetowej, a także procedury budżetowej. Nie są to regulacje wyczerpujące, a niektóre z nich nawet mogą być uznane za zbędne z punktu widzenia standardów poprawnej legislacji. W odniesieniu do problematyki budżetowej związków metropolitalnych uregulowania nie mają jednak charakteru wyczerpującego i stanowią w zasadzie zarys określonej koncepcji statusu finansowego, w tym budżetowego, tych podmiotów. Pozycja finansowoprawna oraz budżetowa związku metropolitalnego musi być zatem kształtowana przy odpowiednim stosowaniu przepisów odrębnych ustaw, a zwłaszcza ustawy o finansach publicznych oraz ustawy o regionalnych izbach obrachunkowych.

Słowa kluczowe: związek metropolitalny; uchwała budżetowa; procedura budżetowa. 


\begin{abstract}
Resolved in 2015 the act on metropolitan unions was meant to be a legal instrument with complex character. It included regulations concerning constitution and tasks of the unions and basics of budget management, as well the budgetary procedures. They are not exhaustive regulations and some of them may be even regarded as needless from point of view of correct legislative standards. However, for the metropolitan unions budgeting issues, the regulations have no comprehensive nature and basically they are only an outline of the financial status concept, including budgetary one, of these entities. The metropolitan union's financial law and budgeting position must be therefore shaped using regulations taken from separate laws, especially, the law on public finances and the law on regional accounting chambers.
\end{abstract}

Keywords: metropolitan union; budgeting resolution; budgeting procedure.

\title{
1. Wprowadzenie
}

Celem opracowania jest analiza zakresu uregulowania problematyki budżetowej w obowiązującej od 1 stycznia 2016 r. ustawie o związkach metropolitalnych $^{1}$. Generalna koncepcja, którą przyjęto $\mathrm{w}$ tej ustawie, polega na kompleksowym uregulowania zasad tworzenia, statusu, struktury i zakresu kompetencji organów takich związków, a także przedmiotowego katalogu zadań realizowanych przez te podmioty oraz fundamentalnych reguł odnoszących się do gospodarki finansowej (w tym budżetowej) związków. Poddano analizie przede wszystkim materiał normatywny i w niezbędnym zakresie dorobek orzeczniczy sądów oraz regionalnych izb obrachunkowych z okresu poprzedzającego wejście w życie tej ustawy, niemniej jednak jego ustalenia mogą być przydatne w wyjaśnieniu zastosowanych przez ustawodawcę rozwiązań dotyczących spraw budżetowych związków metropolitalnych z uwagi na istotne podobieństwo do obowiązujących od ponad 25 lat regulacji procedury i gospodarki budżetowej jednostek samorządu terytorialnego (dalej j.s.t.) i związków tworzonych przez j.s.t.

Ustawa z dnia 9 października 2015 r. o związkach metropolitalnych (Dz.U. poz. 1890, dalej: ustawa). 
Dyskusje o ustroju obszarów metropolitalnych, zakresie ich działania, zadaniach i sposobach finansowania realizacji tych zadań prowadzone są w Polsce od wielu lat ${ }^{2}$. W okresie bezpośrednio poprzedzającym prace legislacyjne nad projektem ustawy o związkach metropolitalnych zgłoszono 30 sierpnia 2013 r. poselski projekt ustawy o powiecie metropolitalnym $^{3}$. Zakładano, że powiat metropolitalny byłby odrębną osobą prawną wykonującą zadania publiczne w imieniu własnym i na własną odpowiedzialność, bez naruszania samodzielności powiatu i gminy. Ustalanie granic powiatu metropolitalnego następowałoby poprzez wskazanie gmin, powiatów lub miast na prawach powiatu wchodzących w skład powiatu metropolitalnego, a zmiana jego granic dokonywana byłaby w sposób zapewniający powiatowi metropolitalnemu terytorium możliwie jednorodne ze względu na układ osadniczy i przestrzenny, uwzględniający więzi społeczne, gospodarcze i kulturowe oraz zapewniający zdolność wykonywania zadań publicznych. Projekt tej ustawy określał: zakres działania i zadania powiatu metropolitalnego, jego władze i zakres ich uprawnień oraz obowiązków, składniki mienia i finanse powiatu metropolitalnego, zasady tworzenia przez powiat metropolitalny związków i stowarzyszeń oraz zawierania porozumień z innymi powiatami i gminami, a także wykonywanie nadzoru nad powiatami metropolitalnymi.

W toku konsultacji zgłaszano różne uwagi do projektu ustawy o powiecie metropolitalnym, dotyczące np.: sposobu określenia formy prawnej i elementów treści studium uwarunkowań i kierunków zagospodarowania przestrzennego w celu wyraźnego odróżnienia tego dokumentu od podobnych dokumentów tworzonych w gminach ${ }^{4}$, ewentualnych konfliktów kompetencyjnych związanych z powstaniem nowej kategorii powiatu ${ }^{5}$, braku wyraźnego rozgraniczenia między powiatem oraz powiatem metro-

2 Zob. np. B. Dolnicki, Koncepcja powiatu metropolitalnego, „Samorząd Terytorialny” 2014, nr 7-8, s. 5-17; B. Dolnicki, Założenia ustawy o powiecie metropolitalnym Górnego Ślq̨ska i Zagłębia [w:] B. Dolnicki (red.), Formy współdziałania jednostek samorzq̨du terytorialnego, Warszawa 2012, s. 86-98.

3 Druk Sejmu RP VII kadencji nr 2107.

4 Pismo Krajowej Izby Urbanistów z dnia 2 października 2013 r., KIU/64/2013, skierowane do Kancelarii Sejmu RP.

5 Pismo Województwa Małopolskiego z dnia 1 października 2013 r., OR-IX.0821.362.2013, skierowane do Biura Związku Województw RP. 
politalnym i de facto wykreowania czwartej kategorii j.s.t. ${ }^{6}$. Negatywnie ten projekt został oceniony przez Związek Powiatów Polskich ${ }^{7}$ oraz bardzo krytycznie przez Konwent Marszałków Województw RP ${ }^{8}$. Z treści opinii sporządzonych na zlecenie Biura Analiz Sejmowych wynika, że generalnie pozytywnie oceniono ideę uregulowania warunków prawnych tworzenia metropolii, ale zgłoszono jednocześnie wiele uwag krytycznych dotyczących np. delimitacji zadań publicznych pomiędzy powiatem metropolitalnym oraz pozostałymi powiatami, statusu powiatu metropolitalnego jako nowej kategorii j.s.t., metod powoływania organów tego powiatu oraz nietypowej roli starosty metropolitalnego, a także ingerencji w system finansowania j.s.t. ${ }^{9} \mathrm{~W}$ wyniku prac w sejmowych Komisjach: Administracji i Cyfryzacji oraz Samorządu Terytorialnego i Polityki Regionalnej na bazie ww. projektu poselskiego powstał projekt ustawy o związkach metropolitalnych ${ }^{10}$.

\section{Związek metropolitalny - istota, status, cel tworzenia}

Zgodnie z ustawą o związkach metropolitalnych związek jest zrzeszeniem j.s.t. położonych $\mathrm{w}$ danym obszarze metropolitalnym. W skład związku metropolitalnego, będącego osobą prawną, wchodzą gminy położone w granicach obszaru metropolitalnego oraz powiaty, na obszarze których leży co najmniej jedna gmina położona w granicach obszaru metropolitalnego. Związek metropolitalny wykonuje zadania publiczne w imieniu

6 Pismo Województwa Zachodniopomorskiego z dnia 3 października 2013 r., GMII.1122.1.214.2013.I.J., skierowane do Biura Związku Województw RP (wyraźnie sugerowano odrzucenie tego projektu). Podobne uwagi krytyczne zawierało pismo Krajowej Rady Izby Architektów RP z dnia 13 listopada 2013 r., L.dz.439/KRIA/2013/w, skierowane do Kancelarii Sejmu RP.

7 Pismo Związku Powiatów Polskich z dnia 28 października 2013 r., Or.A.0531/165/13, skierowane do Kancelarii Sejmu RP.

8 Pismo Związku Województw Rzeczypospolitej Polskiej z dnia 18 grudnia 2013 r., ZW/0714/678/2013, skierowane do Kancelarii Sejmu RP.

9 Opinia z dnia 10 września 2014 r. sporządzona przez prof. dra hab. Czesława Martysza, opinia z dnia 23 kwietnia 2014 r. sporządzona przez dra Maksymiliana Cherkę oraz opinia z dnia 23 kwietnia 2014 r. sporządzona przez dra Pawła Antkowiaka.

10 Sprawozdanie z dnia 4 sierpnia 2015 r. Komisji Administracji i Cyfryzacji oraz Komisji Samorządu Terytorialnego i Polityki Regionalnej - druk nr 3729. 
własnym i na własną odpowiedzialność, a więc w tym zakresie zastosowano analogiczne rozwiązania jak w przypadku już tworzonych związków międzygminnych i związków powiatów. Utworzenie takiego związku następuje w drodze rozporządzenia Rady Ministrów, w którym ustalane są granice poszczególnych obszarów metropolitalnych (poprzez wskazanie gmin wchodzących w ich skład) oraz określana jest nazwa związku. Wydanie rozporządzenia wymaga uprzedniego zasięgnięcia opinii: rad gmin położonych w granicach obszaru metropolitalnego poprzedzonych przeprowadzeniem konsultacji z mieszkańcami; rad powiatów, na obszarze których leży co najmniej jedna gmina położona w granicach obszaru metropolitalnego, a także sejmiku województwa oraz wojewody. Tworząc związek metropolitalny, Rada Ministrów powinna uwzględnić: koncepcję przestrzennego zagospodarowania kraju oraz plan zagospodarowania przestrzennego województwa; powiązania funkcjonalne oraz zaawansowanie procesów urbanizacyjnych, a także jednorodność układu osadniczego i przestrzennego, uwzględniającego więzi społeczne, gospodarcze i kulturowe. Obszarem metropolitalnym powinna być spójna pod względem przestrzennym strefa oddziaływania miasta będącego siedzibą wojewody lub sejmiku województwa, charakteryzująca się istnieniem silnych powiązań funkcjonalnych oraz zaawansowaniem procesów urbanizacyjnych, zamieszkała przez co najmniej 500 tys. mieszkańców.

Zadania związku metropolitalnego można generalnie podzielić na trzy kategorie: określone bezpośrednio w ustawie (tj. kształtowanie ładu przestrzennego, rozwój obszaru związku, publiczny transport zbiorowy na obszarze związku, współdziałanie w ustalaniu przebiegu dróg krajowych i wojewódzkich na obszarze związku, promocja obszaru metropolitalnego), wynikające z porozumienia zawartego z j.s.t. (związek może realizować zadania publiczne należące do zakresu działania gminy, powiatu lub samorządu województwa lub koordynować realizację tych zadań) oraz wynikające z porozumienia zawartego z organem administracji rządowej (związek może realizować zadania publiczne należące do zakresu działania administracji rządowej). 


\section{Zakres regulacji spraw budżetowych w ustawie o związkach metropolitalnych}

Pojęcie „sprawy budżetowe” nie jest zdefiniowane przez ustawodawcę. Nie jest to sytuacja wyjątkowa, ponieważ używane w innych aktach prawnych pojęcia, np. „sprawy podatkowe” czy „sprawy administracyjne”, również nie są definiowane przez ustawodawcę. Wyznaczenia granic pojęcia „sprawy budżetowe” można jednak dokonać z uwzględnieniem postanowień ustawy z dnia 7 października 1992 r. o regionalnych izbach obrachunkowych $^{11}$. W przepisach u.r.i.o. posłużono się pojęciem „sprawy finansowe”, ale analiza postanowień art. 1 ust. 2 w związku z art. 11 ust. 1 u.r.i.o. prowadzi do wniosku, że przedmiotem tych spraw finansowych jest przede wszystkim materia budżetowa, tzn.: procedura uchwalania budżetu i jego zmian; budżet i jego zmiany; zasady i zakres przyznawania dotacji z budżetu j.s.t.; absolutorium; wieloletnia prognoza finansowa. Z niniejszą materią wiążą się pozostałe aspekty działalności finansowej odnoszące się do zaciągania zobowiązań wpływających na wysokość długu publicznego j.s.t. oraz udzielania pożyczek, a także podatków i opłat lokalnych, do których mają zastosowanie przepisy ustawy - Ordynacja podatkowa $^{12}$. Ocenia się, że niniejszy katalog spraw jest doprecyzowaniem przez ustawodawcę konstytucyjnego pojęcia „sprawy finansowe” stosowanego w kontekście konstytucyjnej materii samorządu terytorialnego ${ }^{13}$, przy czym stosowane w Konstytucji RP pojęcie „sprawy finansowe” oznacza przede wszystkim sprawy budżetowe ${ }^{14}$. Zgodnie z art. 1 ust. 2 pkt 1a u.r.i.o. w zakresie wyżej wymienionych spraw finansowych (w tym spraw budżetowych) sprawowany jest nadzór i wykonywana jest kontrola przez r.i.o. nad gospodarką finansową i zamówieniami publicznymi związków metropolitalnych.

11 Tekst jedn. Dz.U. z 2016 r. poz. 561, dalej: u.r.i.o.

12 Ustawa z dnia 29 sierpnia 1997 r. - Ordynacja podatkowa (tekst jedn. Dz.U. z 2015 r. poz. 613 ze zm.).

13 W. Miemiec, Komentarz do art. 11 ust. 1, [w:] M. Stec (red.), Regionalne izby obrachunkowe. Charakterystyka ustrojowa i komentarz do ustawy, Warszawa 2010, s. 311.

14 T. Dębowska-Romanowska, Regionalne izby obrachunkowe - nadzór zewnętrzny nad zarzq̨dzaniem finansowym w samorzq̨dzie i nad tworzeniem lokalnego prawa finansowego [w:] M. Stec (red.), Regionalne izby..., s. 25. 
Ustawa o związkach metropolitalnych nie reguluje w sposób wyczerpujący i kompleksowy spraw budżetowych tych podmiotów. Zakres tych spraw jest zbliżony do pierwotnej koncepcji, którą zastosowano w tzw. ustrojowych ustawach samorządowych ${ }^{15}$, tzn. obok kwestii związanych $\mathrm{z}$ procedurą budżetową względnie obszernie regulowano również w tych ustawach tzw. aspekty materialne związane z: wybranymi źródłami dochodów i przychodów budżetów j.s.t., treścią uchwały budżetowej i jawnością gospodarki finansowej (w tym gospodarki budżetowej). W wyniku kolejnych nowelizacji tych ustaw sukcesywnie ograniczano regulacje o charakterze materialnym, ponieważ są one normowane przepisami odrębnych ustaw ${ }^{16}$, natomiast pozostawiono w nich niektóre uregulowania dotyczące kompetencji organów j.s.t. w sprawach budżetowych i wybranych etapów procedury budżetowej.

Zgodnie z art. 4 ust. 2 u.f.p. przepisy tej ustawy dotyczące j.s.t. stosuje się odpowiednio do związków metropolitalnych. Przyjęcie takiego rozwiązania jest konsekwencją jednoznacznego określenia statusu finansowoprawnego związków metropolitalnych, które zgodnie z art. 9 pkt 2a u.f.p. są jednostkami organizacyjnymi sektora finansów publicznych, podobnie jak związki j.s.t. ${ }^{17}$. W ustawie o związkach metropolitalnych zamieszczono przede wszystkim postanowienia odnoszące się do procedury budżetowej, a jedynie w ograniczonym zakresie uregulowania o charakterze uniwersalnym i ogólnym, związane z prawną instytucją budżetu.

15 Ustawa z dnia 8 marca 1990 r. o samorządzie gminnym (tekst jedn. Dz.U. z 2016 r. poz. 446 ze zm.), ustawa z dnia 5 czerwca 1998 r. o samorządzie powiatowym (tekst jedn. Dz.U. z 2015 r. poz. 1445 ze zm.), ustawa z dnia 5 czerwca 1998 r. o samorządzie województwa (tekst jedn. Dz.U. z 2015 r. poz. 1392 ze zm.).

16 Aktualnie w tym zakresie obowiązują postanowienia ustawy z dnia 27 sierpnia $2009 \mathrm{r}$. o finansach publicznych (tekst jedn. Dz.U. z 2013 r. poz. 885 ze zm., dalej u.f.p.) oraz ustawy z dnia 13 listopada 2003 r. o dochodach jednostek samorządu terytorialnego (tekst jedn. Dz.U. z 2016 r. poz. 198 ze zm.), dalej u.d.j.s.t.

17 E. Ruśkowski, Komentarz do art. 4, [w:] E. Ruśkowski, J.M. Salachna (red.), Finanse publiczne. Komentarz praktyczny, Gdańsk 2013, s. 60. 


\section{Podstawowe rozstrzygnięcia budżetowe dotyczące związków metropolitalnych}

Związek metropolitalny, jako odrębny podmiot prawa, zachowuje również odrębność (samodzielność) finansową od innych jednostek organizacyjnych sektora finansów publicznych, w tym również od j.s.t. oraz od związków j.s.t. Wyrazem tej odrębności są postanowienia art. 42 ustawy, zgodnie z którym związek metropolitalny samodzielnie prowadzi gospodarkę finansową na postawie uchwały budżetowej. Gwarancje ochrony samodzielności finansowej związku metropolitalnego wprowadza natomiast art. 43 tej ustawy stanowiący, że przekazywanie związkowi metropolitalnemu, w drodze ustawy, nowych zadań wymaga zapewnienia środków finansowych koniecznych na ich realizację w postaci zwiększenia dochodów. Przepis ten wprost nawiązuje do konstytucyjnej zasady odpowiedniości (adekwatności) wyrażonej w sposób dynamiczny w art. 167 ust. 4 Konstytucji $\mathrm{RP}^{18}$. Zgodnie z cytowanym przepisem konstytucyjnym zmiany w zakresie zadań i kompetencji j.s.t. następują wraz z odpowiednimi zmianami w podziale dochodów publicznych. Unormowanie powyższe zakłada zatem, że podział zadań publicznych między administrację rządową a samorząd terytorialny nie został dokonany w sposób definitywny i ostateczny ${ }^{19}$. Gwarancja konstytucyjna (gwarancja ustrojodawcy) odnosi się jednak tylko do j.s.t. i nie jest dopuszczalne jej stosowanie, w drodze wykładni rozszerzającej, wobec innych podmiotów sektora samorządowego, w tym również związków tworzonych przez j.s.t. Możliwe jest natomiast formułowanie podobnych gwarancji przez ustawodawcę, $\mathrm{z}$ tym że ich ranga prawna jest niższa od gwarancji wyrażonej wprost $\mathrm{w}$ Konstytucji RP. W odróżnieniu zatem od związków metropolitalnych oraz innych związków tworzonych przez j.s.t. pozycja j.s.t. w zakresie gwarantowania ich dochodów w relacji do przypadających im zadań gwarantowana jest przez ustrojodawcę, bowiem art. 167 Konstytucji RP wraz

18 Konstytucja Rzeczypospolitej Polskiej z dnia 2 kwietnia 1997 r. (Dz.U. Nr 78, poz. 483 ze zm.).

19 E. Kornberger-Sokołowska, Zasada adekwatności w systemie finansów samorzq̨du terytorialnego w Polsce, Warszawa 2013, s. 21. 
z innymi przepisami konstytucyjnymi (art. 16 ust. 2) służy zapewnieniu finansowania zadań publicznych, realizowanych przez j.s.t. we własnym imieniu i na własną odpowiedzialność, czyli w sposób samodzielny, natomiast sądową ochronę samodzielności j.s.t. gwarantuje art. 165 ust. 2 Konstytucji $^{20}$.

W ustawie o związkach metropolitalnych nie wyrażono zasady odpowiedniości (adekwatności) w ujęciu statycznym poprzez odwzorowanie przepisu art. 167 ust. 1 Konstytucji RP stanowiącego, że j.s.t. zapewnia się udział w dochodach publicznych odpowiednio do przypadających im zadań. Przepis ten został sformułowany w sposób kategoryczny i jednoznaczny. Uznano w doktrynie, że wynika z niego nakaz, kierowany do ustawodawcy, precyzyjnego definiowania granic zadań j.s.t. oraz możliwości mierzenia kosztów ich wykonywania ${ }^{21}$.

Zbędne są postanowienia art. 45 ustawy o związkach metropolitalnych, ponieważ stanowią powtórzenie przepisu art. 33 i art. 34 u.f.p., które kreują zasadę jawności i sposoby jej realizacji w sektorze finansów publicznych. Jednoznacznie ustalono, że związki metropolitalne są jednostkami organizacyjnymi tego sektora, a więc wyżej powołane przepisy u.f.p. znajdują do nich również zastosowanie. Zgodnie z § 4 ust. 1 Zasad techniki prawodawczej ${ }^{22}$ ustawa nie może powtarzać przepisów zamieszczonych w innych ustawach, a więc w tym zakresie art. 45 ustawy o związkach metropolitalnych nie spełnia standardu tworzenia prawa. Ponadto należy stwierdzić, że przepis ten reguluje tylko niektóre aspekty jawności gospodarki finansowej związku metropolitalnego, a więc w pozostałym zakresie zachodzi potrzeba stosowania wskazanych wyżej przepisów u.f.p. Z art. 45 omawianej ustawy wynika, że gospodarka środkami finansowymi znajdującymi się $\mathrm{w}$ dyspozycji związku metropolitalnego jest jawna, a wymóg jawności jest spełniany w szczególności przez: jaw-

20 M. Bogucka-Felczak, Sqdowa ochrona praw jednostek samorzqdu terytorialnego do dochodów, „Finanse Komunalne” 2012, nr 3, s. 7; J. Jagoda, Granice samodzielności finansowej jednostek samorzqdu terytorialnego, „Finanse Komunalne” 2014, nr 1-2, s. 16.

21 T. Dębowska-Romanowska, Prawo finansowe, część konstytucyjna wraz z częściq ogólnq, Warszawa 2010, s. 239.

22 Rozporządzenie Prezesa Rady Ministrów z dnia 20 czerwca 2002 r. w sprawie „Zasad techniki prawodawczej” (Dz.U. Nr 100, poz. 908 ze zm.). 
ność debaty budżetowej; opublikowanie uchwały budżetowej oraz sprawozdań z wykonania budżetu związku metropolitalnego; przedstawienie pełnego wykazu kwot dotacji celowych udzielanych z budżetu związku metropolitalnego ${ }^{23}$; ujawnienie sprawozdania zarządu związku z działań dotyczących zaciągania zobowiązań mających pokrycie w ustalonych w uchwale budżetowej kwotach wydatków (w ramach upoważnień udzielonych przez zgromadzenie związku) oraz emitowania papierów wartościowych (w ramach upoważnień udzielonych przez zgromadzenie związku). Z cytowanych przepisów u.f.p. wynika ponadto, że jawność gospodarki finansowej związku metropolitalnego powinna być także realizowana poprzez: jawność debaty nad sprawozdaniem z wykonania budżetu związku; jawność debaty nad projektem uchwały w sprawie wieloletniej prognozy finansowej związku; podawanie do publicznej wiadomości przez związek określonych informacji (tzn. dotyczących: zakresu zadań lub usług wykonywanych lub świadczonych przez związek oraz wysokości środków publicznych przekazanych na ich realizację, zasad i warunków świadczenia usług dla podmiotów uprawnionych, zasad odpłatności za świadczone usługi); zapewnianie delegatom gmin i powiatów wchodzącym w skład zgromadzenia związku dostępu do: dowodów księgowych i dokumentów inwentaryzacyjnych (z zachowaniem przepisów o rachunkowości oraz o ochronie danych osobowych), informacji o wynikach przeprowadzonych kontroli gospodarki finansowej związku, sprawozdania z wykonania planu audytu za rok poprzedni. Ponadto związek obowiązany jest udostępniać wykaz podmiotów spoza sektora finansów publicznych, którym ze środków publicznych dofinansowano realizację zadania lub udzielono pożyczkę oraz umorzono należność wobec związku.

Zasada jawności gospodarki finansowej związku metropolitalnego nie została zatem uregulowana w sposób kompleksowy i wyczerpujący w ustawie o związkach metropolitalnych, a zakres regulacji zawarty w jej art. 45 jest nie tylko niepełny, ale przede wszystkim zbędny z punktu wi-

23 W doktrynie ocenia się, że są to podstawowe sposoby realizacji zasady jawności w sektorze samorządowym - por. R. Kowalczyk, Aktualność zasad budżetowych w ustawie o finansach publicznych, „Finanse Komunalne” 2012, nr 10, s. 35. 
dzenia kryteriów odnoszących się do prawidłowej techniki prawodawczej, ponieważ stanowi powtórzenie postanowień art. 33 i art. 34 u.f.p.

Zgodnie z art. 46 ustawy o związkach metropolitalnych dyspozycja środkami pieniężnymi związku jest oddzielona od jej kasowego wykonania. Analogiczne regulacje są zamieszczone w samorządowych ustawach ustrojowych. Dyspozycja środkami pieniężnymi związku należy generalnie do zakresu kompetencji zarządu związku, który odpowiada za prawidłową gospodarkę finansową związku i w ramach tej odpowiedzialności przysługuje mu m.in. wyłączne prawo do dokonywania wydatków budżetowych, dysponowania rezerwami budżetu związku. Zgodnie z przepisami u.f.p. zarząd związku, jako organ wykonawczy związku, wykonuje budżet związku, a jednocześnie sprawuje ogólny nadzór nad realizacją określonych uchwałą budżetową dochodów i wydatków, przychodów i rozchodów budżetu związku. Operacje finansowe (kasowe), wynikające z dyspozycji wydawanych przez organ wykonawczy związku, są realizowane przez bank wykonujący bankową obsługę budżetu związku na podstawie zawartej umowy rachunku bankowego między zarządem związku i bankiem. Uwzględniając postanowienia art. 264 u.f.p., należy podkreślić, że bankową obsługę budżetu związku wykonuje bank wybrany na zasadach określonych w przepisach o zamówieniach publicznych ${ }^{24}$. Nie oznacza to, że tylko ten jeden bank będzie wykonywał wszystkie operacje finansowe. Zgodnie bowiem z art. 264 ust. 3 i 4 u.f.p. organ stanowiący związku może upoważnić zarząd związku do lokowania wolnych środków budżetowych na rachunkach w innych bankach lub w formie depozytu u Ministra Finansów, a także - w granicach upoważnień zawartych w uchwale budżetowej - może zaciągać kredyty w wybranych przez siebie bankach, w trybie określonym w przepisach o zamówieniach publicznych. W celu zabezpieczenia kredytu lub pożyczki nie można udzielać pełnomocnictwa do dysponowania rachunkiem bankowym związku metropolitalnego.

Z art. 48 ustawy o związkach metropolitalnych wynika, że kontrolę gospodarki finansowej związku sprawuje r.i.o. Przepis ten jest zbędnym powtórzeniem treści art. 1 u.r.i.o., z którego wprost wynika, że r.i.o. spra-

24 Ustawa z dnia 29 stycznia 2004 r. Prawo zamówień publicznych (tekst jedn. Dz.U. z 2015 r. poz. 2164 ze zm.). 
wują nie tylko kontrolę gospodarki finansowej tych związków (art. 1 ust. 1 oraz ust. 2 pkt 1a u.r.i.o.), ale również kontrolę zamówień publicznych i wykonują nadzór nad działalnością związków w zakresie spraw finansowych wyliczonych w art. 11 ust. 1 u.r.i.o. Ponadto, uwzględniając postanowienia art. 13 u.r.i.o., wydają one opinie m.in. o możliwości spłaty kredytu, pożyczki lub wykupu papierów wartościowych; o przedkładanych projektach uchwał budżetowych związków; o przedkładanych przez zarządy związków informacjach o przebiegu wykonania budżetu za pierwsze półrocze; o wnioskach komisji rewizyjnych organów stanowiących związków w sprawie absolutorium oraz opinii w sprawie uchwały zgromadzenia związku o nieudzieleniu zarządowi absolutorium.

Istotne są również postanowienia art. 47 ustawy o związkach metropolitalnych nakazujące odpowiednie stosowanie, przez okres kolejnych trzech lat następujących po roku, w którym utworzono związek (do związku i j.s.t. tworzących ten związek), postanowień art. 244 ust. 1 pkt 2 i ust. 2 oraz art. 245 u.f.p. Powyższe odesłania oznaczają, że do łącznej kwoty przypadających w danym roku budżetowym spłat i wykupów (kredytów, pożyczek, wyemitowanych papierów wartościowych oraz potencjalnych spłat z tytułu udzielonych poręczeń i gwarancji) dodaje się, przypadające do spłaty w tym samym roku budżetowym, kwoty zobowiązań związku współtworzonego przez daną j.s.t. w wysokości proporcjonalnej do jej udziału we wpłatach wnoszonych na rzecz związku, którego jest członkiem. Łączna kwota spłat i wykupów j.s.t. nie obejmuje zobowiązań związku współtworzonego przez tę jednostkę, na które j.s.t. udzieliła gwarancji i poręczeń. Stosownie do postanowień art. 245 u.f.p. do zakresu obowiązków zarządu związku metropolitalnego należy informowanie organów wykonawczych j.s.t. tworzących związek oraz właściwą r.i.o. o kwotach zobowiązań związku, w terminie 15 dni od dnia ich zaciągnięcia. Ocenia się, że uzasadnieniem tej powinności nie są wewnętrzne potrzeby związku związane z prowadzeniem gospodarki finansowej, uchwaleniem jego budżetu lub zaciąganiem zobowiązań przez związek, lecz konieczność posiadania tych informacji przez inne podmioty, tzn. j.s.t., ich zobowiązania bowiem podlegają kumulacji z zobowiązaniami 
związku współtworzonego przez j.s.t. ${ }^{25}$ Umożliwia to również sprawowanie kompleksowego nadzoru przez r.i.o. nad działalnością j.s.t. oraz związków w obszarze ustawowo wskazanych spraw finansowych.

\section{Projekt uchwały pierwszego budżetu związku metropolitalnego}

Podobnie jak w tzw. ustrojowych ustawach samorządowych, także w ustawie o związkach metropolitalnych określono podział kompetencji między organami tego związku w sprawach budżetowych. Uregulowano ponadto funkcje pełnomocnika ds. utworzenia związku metropolitalnego ${ }^{26} \mathrm{w}$ procedurze budżetowej, który wykonuje zadania i kompetencje organów związku metropolitalnego (zgromadzenia związku do dnia jego pierwszej sesji, natomiast zarządu związku do dnia jego wyboru). Projekt uchwały pierwszego budżetu związku powinien być opracowany przez pełnomocnika. Przepis ten wprowadza zatem ustawowy wyjątek od zasady stanowiącej, że organ wykonawczy j.s.t. (związku) jest wyłącznie uprawniony do przygotowania projektu uchwały budżetowej j.s.t. (związku). Niniejszy obowiązek jest elementem składowym szerzej zakreślonego przez ustawodawcę zadania pełnomocnika, a mianowicie organizacyjnego i prawnego przygotowania związku metropolitalnego do wykonywania zadań publicznych. Można stwierdzić, że wyżej wskazane kompetencje pełnomocnika są wzorowane na wprowadzonej w 2011 r. do ustawy o samorządzie gminnym (art. 4e) instytucji pełnomocnika stosowanej w przypadkach łączenia gmin lub tworzenia nowych gmin. Do czasu połączenia gmin lub utworzenia nowej gminy zadaniem pełnomocnika jest przygotowanie organizacyjne i prawne gminy do wykonywania zadań publicz-

25 A. Gorgol, Komentarz do art. 245, [w:] P. Smoleń (red.), Ustawa o finansach publicznych. Komentarz, Warszawa 2014, s. 1194.

26 Pełnomocnik jest wyznaczany przez Prezesa Rady Ministrów, na wniosek wojewody zgłoszony za pośrednictwem ministra właściwego do spraw administracji publicznej, spośród pracowników podległych wojewodzie. Jego obsługę zapewnia właściwy urząd wojewódzki. 
nych, w tym przygotowanie projektu uchwały budżetowej gminy w trybie i na zasadach określonych w przepisach u.f.p.

W ustawie o związkach metropolitalnych nie rozstrzygnięto, w jakim terminie pełnomocnik obowiązany jest opracować projekt uchwały pierwszego budżetu związku. Analizując przepisy ustawy regulujące tworzenie związku oraz rozpoczęcie przez niego działalności, można określić ramy czasowe, w których pełnomocnik powinien opracować projekt uchwały pierwszego budżetu związku. Rozporządzenie Rady Ministrów w sprawie utworzenia związku, zgodnie $\mathrm{z}$ art. 8 ustawy, może być wydane nie później niż 30 kwietnia każdego roku, a związek jest tworzony z dniem 1 lipca i uzyskuje dochody ze źródeł wskazanych w u.d.j.s.t. oraz rozpoczyna realizację swoich zadań z dniem 1 stycznia roku następnego. Wspomniano już wyżej, że przepisy u.f.p. dotyczące j.s.t. stosuje się odpowiednio do związków metropolitalnych, a więc termin dotyczący opracowania projektu uchwały pierwszego budżetu związku wynika z art. 238 u.f.p. Projekt ten pełnomocnik powinien przedstawić, do 15 listopada roku poprzedzającego rok budżetowy, organowi stanowiącemu związku (tzn. zgromadzeniu związku) oraz r.i.o. do zaopiniowania (opinię r.i.o. o projekcie uchwały budżetowej pełnomocnik jest obowiązany przedstawić, przed uchwaleniem budżetu, organowi stanowiącemu związku). Wraz z projektem tej uchwały pełnomocnik obowiązany jest przedłożyć zgromadzeniu związku i r.i.o. uzasadnienie do projektu uchwały budżetowej.

$\mathrm{Z}$ art. 238 ust. 2 pkt 2 u.f.p. wynika również, że wraz z projektem uchwały budżetowej powinny być przedłożone inne materiały określone w uchwale wymienionej w art. 234 u.f.p., tzn. w uchwale organu stanowiącego związku w sprawie trybu prac nad projektem uchwały budżetowej (określa się w niej wymaganą szczegółowość projektu budżetu, terminy obowiązujące w toku prac nad projektem uchwały budżetowej oraz wymogi dotyczące uzasadnienia i materiały informacyjne, które organ wykonawczy przedłoży organowi stanowiącemu wraz z projektem uchwały budżetowej). Można przyjąć, że w momencie opracowywania przez pełnomocnika projektu uchwały pierwszego budżetu związku nie są jeszcze ukonstytuowane organy tego związku, a więc nie została podjęta uchwała w sprawie trybu prac nad projektem uchwały budżetowej związ- 
ku. Uwzględniając jednak postanowienia art. 9 ust. 2 ustawy o związkach metropolitalnych, należy stwierdzić, że pełnomocnik w określonej sytuacji samodzielnie określi tryb prac nad projektem uchwały w sprawie pierwszego budżetu związku, ponieważ zgodnie z tym przepisem ustawy wykonuje on zadania i kompetencje organów związku (w tym organu stanowiącego do dnia jego pierwszej sesji). Zgodnie z art. 21 ust. 1 cytowanej ustawy pełnomocnik do spraw utworzenia związku metropolitalnego zwołuje pierwszą sesję zgromadzenia na dzień przypadający w ciągu 30 dni od utworzenia związku. Jeżeli zatem po 1 lipca danego roku (data utworzenia związku), a przed 15 listopada tego samego roku (ostateczny termin przedłożenia projektu uchwały budżetowej) odbędzie się pierwsza sesja zgromadzenia związku, to pełnomocnik nie może już samodzielnie określić trybu i szczegółowości prac nad projektem uchwały budżetowej, ponieważ zgodnie z art. 234 u.f.p. niniejsza kompetencja będzie wyłącznie przysługiwała organowi stanowiącemu związku metropolitalnego. Podjęcie takiej uchwały przez organ stanowiący jest jego obowiązkiem² ${ }^{27}$, a odstąpienie od tego obowiązku lub jego wykonanie w zakresie węższym od wynikającego z art. 234 u.f.p. jest naruszeniem postanowień tego przepisu ${ }^{28}$.

\section{Przygotowanie, uchwalanie i wykonywanie kolejnych budżetów związku metropolitalnego}

Podział kompetencji między organami związku metropolitalnego w zakresie przygotowania i uchwalenia budżetu związku, przyjęty w ustawie o związkach metropolitalnych, jest zgodny z koncepcją stosowaną w tzw. ustrojowych ustawach samorządowych oraz w u.f.p. Nie jest to jednak pełne odwzorowanie postanowień przyjętych w tych ustawach, a w szczególności ocena powyższa odnosi się do zakresu kompetencji zarządu związku metropolitalnego w sprawach procedury budżetowej. Nie zamieszczono w szczególności przepisu stanowiącego o przygotowywaniu przez zarząd tego związku projektów uchwał, a więc również projektów

27 Uchwała RIO we Wrocławiu z dnia 27 października 2010 r., 86/2010, Legalis nr 306174.

28 Uchwała RIO w Bydgoszczy z dnia 4 sierpnia 2010 r., XVII/41/2010, Legalis nr 250813. 
uchwał budżetowych, natomiast takie przepisy zawierają ustrojowe ustawy samorządowe nakładające na organy wykonawcze j.s.t. oraz organy wykonawcze związków j.s.t. obowiązek przygotowania takich projektów. Kompetencja zarządu związku metropolitalnego odnosząca się do przygotowywania projektu uchwały budżetowej związku powinna zatem być wywodzona wprost z przepisów u.f.p.

Szczegółowo wyliczono natomiast działania tworzące katalog wyłącznych kompetencji zgromadzenia związku metropolitalnego. W katalogu sformułowanym w art. 22 ustawy wymieniono również następujące kategorie spraw budżetowych: uchwalanie budżetu związku metropolitalnego, rozpatrywanie sprawozdania z wykonania tego budżetu, podejmowanie uchwały w sprawie udzielenia lub nieudzielania absolutorium zarządowi związku z tytułu wykonania budżetu związku, podejmowanie uchwał w sprawach majątkowych związku dotyczących ustalania maksymalnej wysokości pożyczek i kredytów krótkoterminowych zaciąganych przez zarząd związku oraz maksymalnej wysokości pożyczek i poręczeń udzielanych przez zarząd w roku budżetowym. W katalogu ustawowym nie wymieniono kompetencji zgromadzenia związku metropolitalnego odnoszącej się do podejmowania uchwały w sprawie prowizorium budżetowego oraz uchwały w sprawie zmiany uchwały budżetowej, ale uwzględniając postanowienia u.f.p. obowiązujące w tym zakresie, należy kategorycznie stwierdzić, że są to również kompetencje wyłącznie przysługujące organowi stanowiącemu związku.

Wprost określono w art. 32 ust. 2 pkt 3 ustawy, że zadaniem zarządu związku jest wykonywanie budżetu związku metropolitalnego. Przepis ten powinien być analizowany łącznie $\mathrm{z}$ art. 44 ustawy stanowiącym niezbędne jego uzupełnienie i stanowiącym, że za prawidłowe wykonanie budżetu związku odpowiada zarząd związku. W szczególności w toku wykonywania budżetu zarządowi przysługuje wyłączne prawo: zaciągania zobowiązań mających pokrycie w ustalonych w uchwale budżetowej kwotach wydatków, w ramach upoważnień udzielonych przez zgromadzenie związku; emitowania papierów wartościowych, w ramach upoważnień udzielonych przez zgromadzenie; dokonywania wydatków budżetowych; zgłaszania propozycji zmian w budżecie związku metropolitalnego; dys- 
ponowania rezerwą budżetu związku metropolitalnego, a także blokowania środków budżetowych w przypadkach określonych u.f.p.

Ustawa o związkach metropolitalnych, podobnie jak tzw. ustrojowe ustawy samorządowe, nie wskazuje kryteriów prawidłowej gospodarki finansami związku. W orzecznictwie sądowym przyjmuje się, że prawidłową jest taka gospodarka, która jest zgodna z prawem i zasadami ekonomii, celowa i rzetelna. Biorąc pod uwagę, że o celach gospodarki finansowej związku w decydującym stopniu przesądza zgromadzenie związku w uchwale budżetowej, należy uznać, że zarząd związku odpowiada głównie za zgodne z prawem oszczędne (ekonomiczne), celowe i rzetelne wydatkowanie. Należy też mieć na uwadze, że na etapie podejmowania uchwały budżetowej nie są możliwymi do przewidzenia wszelkie stany wymagające sfinansowania z budżetu, a także wszystkie okoliczności związane z realizacją przewidzianych w budżecie zadań. Podsumowaniem wykonania budżetu związku jest instytucja absolutorium, która stanowi element zamykający gospodarkę finansową związku i środek kontroli zgromadzenia związku nad działalnością jego organu wykonawczego. Jego przedmiotem jest ocena gospodarki finansowej związku, za prawidłowość której zarząd związku ponosi odpowiedzialność ${ }^{29}$.

Zgodnie z art. 29 ustawy o związkach metropolitalnych uchwałę w sprawie udzielenia zarządowi związku absolutorium zgromadzenie związku podejmuje bezwzględną większością głosów ustawowego składu zgromadzenia. Określono również skutki prawne w przypadku nieprzyjęcia uchwały w sprawie absolutorium, a mianowicie jest to równoznaczne z przyjęciem uchwały w sprawie nieudzielenia zarządowi absolutorium i jednocześnie równoznaczne ze złożeniem wniosku o odwołanie zarządu, chyba że po zakończeniu roku budżetowego zarząd został odwołany $\mathrm{z}$ innej przyczyny. Uchwałę $\mathrm{w}$ sprawie absolutorium zgromadzenie związku podejmuje po zapoznaniu się z wnioskiem komisji rewizyjnej zgromadzenia związku powołanej przez zgromadzenie do kontroli działalności zarządu związku oraz jednostek organizacyjnych utworzonych przez związek. Stosownie do postanowień art. 23 ust. 3 ustawy komisja

29 Por. np. wyrok WSA w Kielcach z dnia 30 października 2013 r., I SA/Ke 554/13, Legalis nr 769332. 
rewizyjna opiniuje wykonanie budżetu związku metropolitalnego i występuje $\mathrm{z}$ wnioskiem do zgromadzenia w sprawie udzielenia lub nieudzielenia absolutorium zarządowi związku. Wniosek w tej sprawie podlega zaopiniowaniu przez r.i.o. Rozpoznanie wniosku o odwołanie zarządu następuje na sesji zwołanej nie wcześniej niż po upływie 14 dni od podjęcia uchwały w sprawie nieudzielenia zarządowi absolutorium. Po zapoznaniu się z wnioskiem komisji rewizyjnej i opinią r.i.o. zgromadzenie związku może odwołać zarząd związku większością co najmniej 3/5 głosów ustawowego składu zgromadzenia, w głosowaniu tajnym. Organ stanowiący związku nie jest związany treścią wniosku komisji rewizyjnej, który według dotychczasowego dorobku orzeczniczego sądów administracyjnych traktowany jest jako niewiążąca organ stanowiący propozycja w sprawie absolutorium, a nie dyspozycja określonego zachowania ${ }^{30}$.

\section{Uwagi końcowe}

Uchwalenie ustawy o związkach metropolitalnych jest znaczącym osiągnięciem $\mathrm{w}$ procesie kontynuowania reformy samorządu terytorialnego w Polsce, w szczególności w sferze tworzenia warunków umożliwiających rozwiązywanie istotnych problemów dotyczących wielu położonych obok siebie j.s.t., w tym w drodze koordynacji i bezpośredniej współpracy. Zrealizowanie inicjatywy ustawodawczej wpisuje się w efekty konsultacji tzw. Zielonej Księgi dotyczącej obszarów metropolitalnych, przedstawionej 29 czerwca 2012 roku na posiedzeniu Komisji Wspólnej Rządu i Samorządu Terytorialnego, w których wskazano, że docelowym rozwiązaniem instytucjonalnym powinien być obszar metropolitalny. Model ten powinien być stosowany $\mathrm{w}$ odniesieniu do najbardziej zintegrowanych polskich aglomeracji, szczegółowo identyfikowanych w przyjętej przez Sejm RP 15 czerwca 2012 roku Koncepcji Przestrzennego Zagospodarowania Kraju 2030 (KPZK 2030). Możliwości rozwiązywania problemów, wynikających np. z codziennej migracji mieszkańców pomiędzy j.s.t.,

30 Por. np. wyrok WSA w Gdańsku z dnia 14 listopada 2012 r., I SA/Gd 1060/12, Legalis nr 867472. 
potrzeb w sferze infrastruktury, transportu, zagrożeń dla środowiska naturalnego, są ograniczone z uwagi na potencjał dochodowy poszczególnych j.s.t. Problemów tych nie rozwiązano również w drodze tworzonych dobrowolnie związków komunalnych lub dobrowolnie zawieranych porozumień.

Rozwiązania przyjęte w ustawie o związkach metropolitalnych będą mogły znaleźć praktyczne zastosowanie dopiero w momencie wydawania przez Radę Ministrów stosownych aktów wykonawczych, określających obszary metropolitalne. Koncepcja uchwalonej w 2015 r. ustawy o związkach metropolitalnych zakłada określone kompleksowe rozwiązania (ustrojowe, organizacyjne, kompetencyjne oraz finansowe). Przeprowadzona w niniejszym opracowaniu analiza regulacji problematyki budżetowej, zawartych w tej ustawie, pozwala na sformułowanie oceny co najwyżej zadowalającej. Ustawodawca nie uniknął błędu polegającego na zamieszczeniu w niej wielu postanowień stanowiących zbędne powtórzenia unormowań wynikających przede wszystkim z przepisów u.f.p. Pozytywnie natomiast należy ocenić te rozwiązania, które wprowadzają formalne gwarancje stabilności gospodarki budżetowej prowadzonej przez związek metropolitalny, w szczególności jest to zasada odpowiedniości (adekwatności) dochodów i zadań związku. Zmiany wprowadzone ustawą o związkach metropolitalnych do innych ustaw, zwłaszcza do ustawy o dochodach j.s.t. prowadzą do wykreowania źródeł dochodów tych związków $^{31}$. Oznacza to, że status związku metropolitalnego w aspekcie budżetowym, w porównaniu do statusu innych rodzajów związków komunalnych (międzygminnych, powiatowo-gminnych lub powiatowych) jest generalnie stabilniejszy. Konkludując, związek metropolitalny - jako odrębny i samodzielny pod względem finansowym podmiot prawa - powinien stać się istotnym dopełnieniem ustroju samorządu terytorialnego w Polsce. Jego zakres działania nie powinien prowadzić do naruszenia odrębności i samodzielności j.s.t. tworzących ten związek. Jednocześnie uniwersalne założenia, na których opiera się koncepcja tworzenia związków metropolitalnych, powinny przyczyniać się do większej koordynacji działań j.s.t. oraz nawiązania ściślejszej między nimi współpracy. W re-

31 Z uwagi na obszerny zakres problemów związanych ze źródłami dochodów związków metropolitalnych ich analiza będzie zamieszczona w odrębnym opracowaniu. 
zultacie może to skutkować większą efektywnością działania j.s.t. oraz zaspokajania potrzeb wspólnot lokalnych.

\section{Bibliografia:}

Bogucka-Felczak M., Sq̨dowa ochrona praw jednostek samorzqdu terytorialnego do dochodów, „Finanse Komunalne” 2012, nr 3, s. 5-13.

Dębowska-Romanowska T., Prawo finansowe, część konstytucyjna wraz z częściq ogólnq, C.H. Beck, Warszawa 2010.

Dębowska-Romanowska T., Regionalne izby obrachunkowe - nadzór zewnętrzny nad zarzq̨dzaniem finansowym w samorzqdzie i nad tworzeniem lokalnego prawa finansowego [w:] M. Stec (red.), Regionalne izby obrachunkowe. Charakterystyka ustrojowa i komentarz do ustawy, Wolters Kluwer Polska, Warszawa 2010.

Dolnicki B., Koncepcja powiatu metropolitalnego, „Samorząd Terytorialny” 2014, nr 7-8, s. 5-17.

Dolnicki B., Założenia ustawy o powiecie metropolitalnym Górnego Ślqzska i Zagłębia, [w:] B. Dolnicki (red.), Formy współdziałania jednostek samorzqdu terytorialnego, Lex a Wolters Kluwer business, Warszawa 2012, s. 86-98.

Gorgol A., Komentarz do art. 245, [w:] P. Smoleń (red.), Ustawa o finansach publicznych. Komentarz, C.H. Beck, Warszawa 2014.

Jagoda J., Granice samodzielności finansowej jednostek samorzq̨du terytorialnego, „Finanse Komunalne” 2014, nr 1-2, s. 12-20.

Kornberger-Sokołowska E., Zasada adekwatności w systemie finansów samorzqdu terytorialnego w Polsce, Lexis Nexis, Warszawa 2013.

Kowalczyk R., Aktualność zasad budżetowych w ustawie o finansach publicznych, „Finanse Komunalne” 2012, nr 10, s. 30-35.

Miemiec W., Komentarz do art. 11 ust. 1, [w:] M. Stec (red.), Regionalne izby obrachunkowe. Charakterystyka ustrojowa i komentarz do ustawy, Wolters Kluwer Polska, Warszawa 2010.

Ruśkowski E., Komentarz do art. 4, [w:] E. Ruśkowski, J.M. Salachna (red.), Finanse publiczne. Komentarz praktyczny, Ośrodek Doradztwa i Doskonalenia Kadr, Gdańsk 2013. 